\title{
Is Behçet's disease triggered by childhood infection?
}

\author{
C COOPER, ${ }^{1}$ E C PIPPARD,${ }^{1}$ H SHARP,${ }^{2}$ C WICKHAM,${ }^{1}$ M A CHAMBERLAIN, \\ AND D J P BARKER
}

From the ${ }^{1}$ MRC Environmental Epidemiology Unit, University of Southampton, Southampton General Hospital, Southampton and the ${ }^{2}$ Rheumatology and Rehabilitation Research Unit, University of Leeds Medical School, Clarendon Road, Leeds

SUMMARY In a comparison of 30 patients with Behçet's disease and 60 age and sex matched community controls an increased risk of Behçet's disease was associated with tonsillectomy, a history of cold sores, large sibship size, late birth order, travel to countries with high incidence of the disease, and first sexual intercourse before 16 years of age. These findings are consistent with a triggering of the disease by infection during childhood or adolescence in an immunogenetically predisposed host.

Key word: epidemiology.

Behçet's disease is a chronic systemic disease of unknown aetiology characterised by a multiorgan vasculitis. ${ }^{1}$ Diagnostic criteria for the disease are not generally agreed but usually gather the clinical features into major and minor groups. ${ }^{2}$

The strong association between Behçet's disease and the HLA-B5 antigen, reported from Turkey ${ }^{3}$ and Japan ${ }^{4}$ but not from Western countries, ${ }^{5}$ has led to the pathogenetic model of an immune complex vasculitis triggered by an environmental agent in a genetically susceptible host. The nature of the trigger is not known. Evidence from immunological and DNA hybridisation studies has suggested type 1 herpes simplex virus infection. ${ }^{6-8}$ Two case-control studies from Japan have raised the possibility of exposure to agricultural chemicals and organic pesticides. ${ }^{9} 10$

We report a case-control study in northern England which examined possible medical, social, and occupational risk factors for the disease.

\section{Patients and methods}

The patients were selected from a case register of Behçet's disease maintained at the rheumatology and rehabilitation research unit in Leeds from 1977 to 1986 . They comprised 13 men and 17 women on this register who fulfilled criteria for complete or incomplete Behçet's disease ${ }^{1}$ and who were born in

Accepted for publication 16 August 1988.

Correspondence to Dr C Cooper, Rheumatology Unit. Bristol Royal Infirmary, Bristol BS2 8HW. the United Kingdom. Although most of the patients were resident in Yorkshire, 10 lived in other regions in the north of England.

Each patient was compared with two community controls, matched for sex and year of birth, who were randomly selected from the patient list of the general practitioner attending the case. If a control declined to participate in the study a substitute was selected. The response rate among first selected controls was $72 \%$, with 17 substitute controls required to complete the series of 60 .

All the cases and controls were interviewed by a single trained interviewer (HS) using a structured questionnaire. Information was obtained about their place of birth and subsequent residence, occupation, contact with animals, history of foreign travel,

Table 1 Clinical manifestations in 30 patients with complete or incomplete Behçet's disease

\begin{tabular}{lll}
\hline Classification & Manifestation & $\begin{array}{l}\text { Number of } \\
\text { patients }\end{array}$ \\
\hline Major & Oral ulceration & 30 \\
& Genital ulceration & 27 \\
& Skin complaints (all) & 20 \\
& Eye complaints (all) & 17 \\
Minor & Arthritis & 22 \\
& Neurological disorder & 8 \\
& Gastrointestinal disorder & 6 \\
& Cardiovascular disorder & 6 \\
& Epididymitis & 1 \\
\hline
\end{tabular}


Table 2 Individual risk factors for Behçet's disease

\begin{tabular}{|c|c|c|c|c|c|c|}
\hline Variable & $\begin{array}{l}\text { Number of } \\
\text { patients } \\
(n=30)\end{array}$ & $\begin{array}{l}\text { Number of } \\
\text { controls } \\
(n=60)\end{array}$ & $\begin{array}{l}\text { Relative } \\
\text { risk }\end{array}$ & $\begin{array}{l}95 \% \\
\text { Confidence } \\
\text { interval }\end{array}$ & $\chi^{\prime}(d f)$ & $\begin{array}{l}\text { Significanc } \\
\text { level } \\
\text { (p value) }\end{array}$ \\
\hline \multicolumn{7}{|l|}{ History of oral ulceration before } \\
\hline 14 years of age & 15 & 11 & $4 \cdot 4$ & $1 \cdot 6$ to $15 \cdot 2$ & $9 \cdot 3(1)$ & $0 \cdot(x) 2$ \\
\hline Previous tonsillectomy & 19 & 14 & $4 \cdot 7$ & 1.8 to 11.9 & $11 \cdot 9(1)$ & $<() \cdot(x) 1$ \\
\hline Consulted doctor for cold sores & 7 & 4 & $3 \cdot 5$ & $1 \cdot 0$ to $11 \cdot 9$ & $4 \cdot 2(1)$ & $0 \cdot(04$ \\
\hline \multicolumn{7}{|l|}{ Family size (excluding subject) } \\
\hline$\leqslant 1$ & 7 & 24 & $1 \cdot()$ & - & \multirow{3}{*}{$5 \cdot 5(2)$} & \multirow{3}{*}{$0 \cdot(06$} \\
\hline $2-3$ & 9 & 23 & $1 \cdot 3$ & 0.5 to 3.8 & & \\
\hline $4+$ & 14 & 13 & $3 \cdot 3$ & $1 \cdot 1$ to $10 \cdot 0$ & & \\
\hline \multicolumn{7}{|l|}{ Birth order } \\
\hline 1 & 10 & 29 & $1 \cdot 0$ & - & \multirow{2}{*}{$3.9(2)$} & \multirow{2}{*}{$0 \cdot 14$} \\
\hline $3+$ & 14 & 15 & $2 \cdot 5$ & 0.9 to 6.7 & & \\
\hline \multicolumn{7}{|l|}{ First sexual intercourse before } \\
\hline 16 years of age & 8 & 3 & $13 \cdot 1$ & 1.6 to $106 \cdot 7$ & $9 \cdot 5(1)$ & $0 \cdot(002$ \\
\hline \multicolumn{7}{|l|}{ Visit to Mediterranean littoral. } \\
\hline onset of Behçet's disease & 6 & 4 & $3 \cdot 6$ & 0.9 to 14.5 & $3 \cdot 4(1)$ & 0.07 \\
\hline
\end{tabular}

childhood socioeconomic circumstances, medical, drug, and sexual history. The patients were examined by a consultant rheumatologist (MAC) at the time of presentation and had a venous blood sample taken for estimation of herpes simplex virus DNA as previously described. ${ }^{7}$

The data were analysed using conditional logistic regression for matched case-control studies. ${ }^{1 \mathrm{P}}$

\section{Results}

The mean age of the 30 patients with Behçet's disease was $42 \cdot 2$ years (range 16-65) with the mean age at onset $29 \cdot 1$ years (range 7-58). Nine fulfilled criteria for complete Behçet's disease. Table 1 shows the clinical manifestations of the patients. Twenty seven patients had orogenital involvement, with skin and eye features being less prevalent. Arthritis was the most frequently encountered minor clinical manifestation. Eleven patients $(37 \%)$ had raised levels of herpes simplex virus DNA in their peripheral blood on at least one occasion.

Table 2 shows the distribution among the 33 investigated of those variables which were most closely associated with the risk of Behçet's disease. Differences are expressed as relative risk of Behçet's disease. History of oral ulceration before 14 years of age, tonsillectomy, and consultation with a doctor for cold sores were associated with three to fivefold increases in relative risk, which were statistically significant.

Increased risk was also associated with having four or more siblings or being a later born child. The trends with family size and birth order did not attaio statistical significance. First sexual intercourse be fore the age of 16 years was associated with statistically significant increase in risk. Risk was no related, however, to lifetime number of sexua partners, number of sexual partners before disease onset, and use of the oral contraceptive pill.

Travel before the onset of the disease to the Mediterranean littoral, Middle East, or Japan, a areas with high incidence, was associated with ap increased risk. There was, however, no relatio between risk and travel to other parts of the world frequency of illness abroad, or time spent abroad

Risk was not related to contact with domestic of agricultural animals, occupational history, or expos sure to herbicides and pesticides.

\section{Discussion}

In a comparison of a series of patients with Behçet 'No disease in northern England and controls draw from the community we have shown that the risk the disease is related to oral ulceration in childhood tonsillectomy, cold sores requiring consultation with a doctor, and first sexual intercourse before 16 year\$ of age. Risk is also related to larger families, late? birth order, and travel to the Mediterranean littorab Middle East, or Japan before the onset of sympa toms.

Epidemiological studies of Behçet's disease is Britain are difficult. The condition is rare and the 
small number of identifiable cases limits the statistical power of a study. The diagnostic criteria we used were chosen to restrict entry into the study of less well established cases and thereby to increase the precision with which risk factors could be identified. The use of these criteria, however, led to the exclusion of almost half of the patients listed on the Yorkshire register. Furthermore, the large number of variables studied requires that caution be exercised in interpreting the significance of the relative risks obtained as at least one statistically significant result would be expected by chance.

The pathogenetic model for Behçet's disease is that of an environmental agent triggering the condition in an immunogenetically susceptible host. ${ }^{12}$ The immunological susceptibility is suggested by the higher prevalence of HLA-B5, a class 1 gene product of the major histocompatibility complex, in patients with the disease. ${ }^{34}$ The geographical predilection of Behçet's disease for the Mediterranean littoral, Turkey, the Middle East, and Japan, however, is not explained by differences in the prevalence of HLA-B5. ${ }^{13}$ This observation, coupled with our finding of an increased risk in travellers to areas of high disease prevalence, suggests that the geography of the disease is explained by variable exposure to the environmental trigger.

The identity of this environmental trigger remains unknown. The three agents which have been proposed are exposure to agricultural chemicals, ${ }^{9} 10$ contact with certain animals, ${ }^{14}$ and infection with type 1 herpes simplex virus. ${ }^{6-8}$ We have been unable to detect any association between Behçet's disease and exposure to agricultural chemicals or contact with animals. Our finding of an increased risk of disease in people who had consulted a doctor for cold sores supports an association with type 1 herpes simplex virus infection. Type 1 herpes simplex virus may be one of a number of pathogens which trigger Behçet's disease singly or in combination. Alternatively, Behçet's disease may be caused by an immunological dysfunction which also predisposes to herpes simplex virus infection.

The associations between Behçet's disease and tonsillectomy, family size, and birth order are open to various interpretations. Although the association with tonsillectomy may reflect recall bias in patients whose disease manifests with oropharyngeal ulceration, such bias is unlikely to explain the associations with family size and birth order. Later born children in large families are more exposed to childhood infection. Tonsillectomy may be a marker for such children. The incidence of tonsillectomy has declined over recent decades, ${ }^{15}$ but the prevalence estimate for reported tonsillectomy in our control group $(23 \%)$ is comparable with those obtained in community control groups of case-control studies both in the United States ${ }^{16}$ and the United Kingdom. ${ }^{17}$

In conclusion, our findings are consistent with a triggering of Behçet's disease in the United Kingdom by infection during childhood or adolescence.

We thank Dr J Bird-Stewart for providing the herpes simplex virus DNA results on the 30 patients with Behçet's disease and Mrs B Wilde for typing the manuscript.

\section{References}

1 Shimizu T, Ehrlich G E, Inaba G, Hayashi K. Behçet's disease (Behcet's syndrome). Semin Arthritis Rheum 1979; 8: 223-60.

2 Lehner T, Barnes C G. Criteria for diagnosis and classification of Behçet's disease. In: Lehner T, Barnes C G, eds. Behçet's syndrome: clinical and immunological features. New York: Academic Press, 1979: 1-9.

3 Yazici H, Akokan G, Yalcin B, Muftuoglu A. The high prevalence of HLA B5 in Behçet's disease. Clin Exp Immunol 1977; 30: 259-61.

4 Ohno S, Aoki K, Sugiura S, Nakayama E, Itakura K, Aizawa M. HL-A5 and Behçet's disease. Lancet 1973; ii: 1383-4.

5 Bird Stewart J A. Genetic analysis of families of patients with Behçet's syndrome: data incompatible with autosomal recessive inheritance. Ann Rheum Dis 1986; 45: 265-8.

6 Eglin R P, Lehner T, Subak-Sharpe J H. Detection of RNA complementary to herpes simplex virus in mononuclear cells from patients with Behçet's syndrome and recurrent oral ulcers. Lancet 1982; ii: 1356-61.

7 Bonass W A, Bird-Stewart J A, Chamberlain M A, Halliburton I W. Molecular studies in Behçet's syndrome. In: Lehner T, Barnes C G, eds. Recent advances in Behçet's disease. London: Royal Society of Medicine Services, 1986: 37-42.

8 Pugh C J, Lehner T. The proliferative responses of separated and reconstituted $\mathrm{T} 4$ and $\mathrm{T} 8$ cells to herpes simplex virus in Behçet's disease. In: Lehner T, Barnes C G, eds. Recent advances in Behçet's disease. London: Royal Society of Medicine Services, 1986: 43-50.

9 Jimi S, Kuratsune M. Epidemiological studies on Behçet's disease. 2. A case control study on Behçet's disease. Japanese Journal of Public Health 1976; 23: 759-86.

10 Tanaka K, Kajiyama K, Imamura T, et al. Genetic and environmental factors in the development of Behçet's disease. Tohoku J Exp Med 1985; 145: 205-13.

11 Breslow N E, Day N E. Conditional logistic regression for matched sets. In: Breslow N E, Day N E, eds. Statistical methods in cancer research. Vol 1. The analysis of case control studies. Lyon: International Agency for Research on Cancer, 1980: 248-79.

12 Welsh K I, Kerr L A. The immunogenetics of Behçet's disease-do they give an indication to the likely mechanism for the disease. In: Lehner T. Barnes C G, eds. Recent advances in Behçet's disease. London: Royal Society for Medicine Services, 1986: 3-9.

13 Chamberlain M A. Behçet's syndrome in 32 patients in Yorkshire. Ann Rheum Dis 1977; 36: 491-9.

14 Larsson H, Bengtsson-Stigmar E. Behçet's disease and close contact with pigs. Acta Med Scand 1984; 216: 541-3.

15 Maw A R. Tonsillectomy today. Arch Dis Child 1986; 61: 421-3.

16 Wolfe F, Young D Y. Rheumatoid arthritis and antecedent tonsillectomy. J Rheumatol 1983; 10: 309-12.

17 Patel S B, Eastmond C J. Preceding tonsillectomy and appendectomy in rheumatoid and degenerative arthritis. $J$ Rheumatol 1983; 10: 313-5. 